\title{
Sebaran Vektor Penyakit Demam Berdarah (Aedes aegypti) di Kampus Universitas Islam Bandung
}

\author{
Ratna Dewi Indi Astuti, ${ }^{1}$ Ismawati, ${ }^{1}$ Listya Hanum Siswanti, ${ }^{2}$ Alimmatin Suhartini ${ }^{3}$ \\ ${ }^{1}$ Bagian Parasitologi, ${ }^{2}$ Bagian Histologi, ${ }^{3}$ Mahasiswa Fakultas Kedokteran Unisba
}

\begin{abstract}
Abstrak
Demam berdarah dengue ialah penyakit disebabkan oleh virus dengue yang ditularkan melalui vektor nyamuk Aedes aegypti. Untuk mengendalikan vektor dilakukan upaya pemberantasan sarang nyamuk (PSN) sehingga dapat dicapai angka bebas jentik lebih dari 95\%. Penelitian ini bertujuan mengetahui kepadatan jentik Aedes aegypti serta kepadatan nyamuk betina dewasa di kampus Unisba. Penelitian ini bersifat observasional dan survei jentik dilakukan di Universitas Islam Bandung (Unisba) pada bulan Juni 2015. Kepadatan jentik diukur dengan parameter indeks kontainer. Kepadatan nyamuk betina dewasa diukur dengan menghitung indeks ovitrap. Hasil penelitian menunjukkan lingkungan Kampus Unisba belum bebas jentik (indeks kontainer=17\%) dengan kepadatan terbesar di Gedung Pascasarjana (24\%). Ovitrap indeks di Kampus Unisba 41\% dengan proporsi positif terbesar di Gedung Fakultas Kedokteran Unisba Jalan Tamansari 22 dan Gedung Rektorat (masing-masing 57\%). Simpulan, Kampus Unisba bukan merupakan daerah bebas jentik nyamuk Aedes aegypti dan tersebar vektor penyebar penyakit demam berdarah, yaitu nyamuk betina dewasa Aedes aegypti.
\end{abstract}

Kata kunci: Indeks kontainer, jentik, nyamuk dewasa betina Aedes aegypti, ovitrap

\section{Dengue's Vector Distribution (Aedes aegypti) at Bandung Islamic University Campus}

\begin{abstract}
Dengue hemorrhagic fever is a disease caused by dengue virus that is transmitted by Aedes aegypti. Mosquito nest eradication (Pemberantasan Sarang Nyamuk) in order to achieve free larva numbers more than 95\% is important to control vectors. This study determined the density of larva and the adult female of Aedes aegypti in Universitas Islam Bandung (Unisba's campus) environment. The larvae survey was conducted on Unisba's campus in June 2015. The density of larva was counted by container index. The density of adult female assesed by ovitrap index. The results showed that Unisba's campus environment was not free from larva (container index=17\%) with the greatest density was in the pascasarjana building (24\%).The ovitrap index on Unisba's campus was $41 \%$ with the largest proportion was in Medical Faculty Unisba Tamansari 22 and rectorate building (each 57\%). In conclusion, Unisba's campus is not an free area of Aedes aegypti larvae and adults female of Aedes aegypti spreaded there.
\end{abstract}

Key words: Adult female Aedes aegypti, container index, larva, ovitrap

Korespondensi: E-mail: dr_ratnadewi@yahoo.com, isma.fkunisba@yahoo.com, hanumlist@gmail.com 


\section{Pendahuluan}

Demam berdarah dengue (DBD) adalah penyakit yang disebabkan oleh virus dengue. Penyakit ini dapat menyebabkan kematian karena perdarahan dan juga gangguan hemodinamika. Penyakit ini ditularkan melalui gigitan nyamuk Aedes aegypti dengan cara mentransmisikan virus dengue dari penderita kepada orang sehat. ${ }^{1}$

World Health Organization (WHO) telah memperkirakan 50-100 juta orang terinfeksi demam berdarah dengue setiap tahunnya dengan case fatality rate (CFR) di negara berkembang berkisar antara $1 \%$ sampai $2,5 \%$ sehingga untuk setiap 100 kasus demam berdarah dengue akan didapatkan $1-3$ orang meninggal dunia karena penyakit DBD tersebut. ${ }^{2}$ DBD juga menimbulkan kejadian luar biasa (KLB) DBD lima tahunan di Indonesia, seperti dilaporkan Kemenkes RI pada tahun 2009 terjadi 158.912 kasus demam berdarah dengue di Indonesia. Angka kejadian DBD di Provinsi Jawa Barat menduduki peringkat yang keenam se-Indonesia, serta Kota Bandung merupakan salah satu kota besar di Jawa Barat dengan angka kejadian DBD yang tinggi. ${ }^{3}$

Angka kejadian DBD yang terus meningkat setiap tahun disebabkan oleh pengendalian vektor yang lemah. Salah satu upaya untuk pengendalian vektor adalah pemberantasan sarang nyamuk (PSN). Pemerintah mencanangkan gerakan $3 \mathrm{M}$ untuk pemberantasan sarang nyamuk, yaitu menutup tempat penampungan air, mengubur barang-barang bekas yang dapat menjadi sarang nyamuk, dan menguras tempat penampungan air pada setiap minggu secara teratur. Pemerintah RI telah menargetkan angka bebas jentik lebih dari 95\% untuk mengendalikan nyamuk Aedes aegypti, tetapi target tersebut belum tercapai. ${ }^{3}$ Nyamuk dewasa Aedes aegypti berkembang biak di tempat-tempat penampungan air bersih di dalam atau di sekitar rumah, berupa genangan air yang tertampung atau bejana seperti bak mandi, dispenser, serta barang-barang bekas yang dibuang sembarangan dan akan terisi air saat hujan. ${ }^{4}$

Aedes aegypti memiliki sifat diurnal. Pada siang hari nyamuk yang betina akan menghisap darah untuk pematangan telurnya. ${ }^{4}$ Demikian pula manusia bersifat diurnal yang berkegiatan pada waktu siang hari. Kampus Universitas Islam Bandung (Unisba) merupakan salah satu tempat aktivitas mahasiswa, dosen, dan pegawai lainnya yang menghabiskan waktu di siang hari. Dengan demikian, kampus berpotensi menjadi tempat penularan bilamana terdapat kasus DBD dan vektornya di lingkungan di sekitar Kampus Unisba Tamansari. Dalam rangka pengendalian vektor untuk pencegahan penyebaran penyakit demam berdarah dengue di Kampus Unisba, peneliti tertarik untuk mengkaji keberadaan dan kepadatan jentik maupun nyamuk betina dewasa Aedes aegypti di lingkungan Kampus Unisba.

\section{Metode}

Penelitian observasional dilakukan di Kampus Universitas Islam Bandung (Unisba) pada bulan Juni 2015. Penelitian survei jentik dilaksanakan pada tempat-tempat penampungan air bersih di lingkungan Kampus FK Unisba. Data yang diperoleh kemudian diperlihatkan dalam bentuk tabel dan persentase. Kepadatan jentik nyamuk itu diukur dengan parameter indeks kontainer, yaitu persentase jumlah tempat penampungan air bersih yang positif terdapat jentik nyamuk Aedes aegypti terhadap jumlah keseluruhan tempat penampungan air bersih yang diperiksa.

Kepadatan nyamuk Aedes aegypti dinilai dengan indeks ovitrap, yaitu proporsi ovitrap yang mengandung telur Aedes aegypti terhadap seluruh jumlah ovitrap yang disebar di Kampus Unisba. Ovitrap yang dipergunakan itu adalah ember warna hitam kecil yang dilapisi kertas saring pada dinding bagian dalam dan diberi air sumur setinggi $4 \mathrm{~cm}$. Ovitrap disebar di seluruh bagian gedung Kampus FK Unisba dan berjarak sekitar 50 meter antarember. Setelah 48 jam, ember ovitrap dikumpulkan kembali kemudian diperiksa keberadaan telur-telur nyamuk Aedes aegypti pada kertas saring. Jumlah persentase ovitrap positif telur Aedes aegypti atau indeks ovitrap pada setiap lokasi gedung Kampus Unisba ditampilkan dalam bentuk tabel.

\section{Hasil}

Berdasarkan survei kepadatan jentik diperoleh indeks kontainer Kampus Unisba sebesar 17\% 
84 Sebaran Vektor Penyakit Demam Berdarah (Aedes aegypti) di Kampus Universitas Islam Bandung

Tabel 1 Kepadatan Jentik Aedes aegypti pada Bulan Juni 2015 di Lingkungan Kampus Unisba

\begin{tabular}{lcccc}
\hline \multirow{2}{*}{ Lokasi } & \multicolumn{2}{c}{ Jumlah Kontainer Air Bersih } & Indeks \\
\cline { 2 - 4 } & Positif Jentik & Negatif Jentik & Jumlah & Kontainer \\
\hline FK Unisba (Tamansari 22) & 2 & 16 & 18 & $11 \%$ \\
Rektorat & 2 & 12 & 14 & $14 \%$ \\
Pascasarjana Unisba & 7 & 22 & 29 & $24 \%$ \\
Tamansari 20 & 0 & 3 & 3 & $0 \%$ \\
Jumlah & 11 & 53 & 64 & $17 \%$ \\
\hline
\end{tabular}

(Tabel 1). Lokasi pada survei yang mempunyai jumlah penampungan air bersih yang terbanyak mengandung jentik adalah Gedung Pascasarjana Unisba dengan tempat/wadah penampungan air bersih berupa pot tanaman air dan dispenser. Penampungan air bersih yang mengandung jentik di Gedung Fakultas Kedokteran Unisba Jalan Tamansari 22 adalah alas pot, sedangkan penampungan air bersih yang terdapat jentik di Gedung Rektorat Unisba adalah bak mandi. masing-masing (Tabel 2).

\section{Pembahasan}

Suatu lingkungan dinyatakan bebas jentik jika indeks kontainer kurang dari $5 \%$, oleh karena itu lingkungan Unisba yang memiliki indeks kontainer $17 \%$ belum dapat dinyatakan sebagai daerah bebas jentik. Lingkungan yang belum bebas jentik bukan saja di lingkungan Kampus

Tabel 2 Jumlah Ovitrap yang Mengandung Telur Aedes aegypti

\begin{tabular}{|c|c|c|c|c|c|c|}
\hline \multirow[b]{2}{*}{ Lokasi } & \multicolumn{2}{|c|}{ Indoor } & \multicolumn{2}{|c|}{ Outdoor } & \multirow[b]{2}{*}{ Total } & \multirow{2}{*}{$\begin{array}{c}\text { Propors } \\
\text { Ovitrap } \\
(+)\end{array}$} \\
\hline & $\begin{array}{c}\text { Ovitrap } \\
(+)\end{array}$ & $\begin{array}{c}\text { Ovitrap } \\
(-)\end{array}$ & $\begin{array}{c}\text { Ovitrap } \\
(+)\end{array}$ & $\begin{array}{c}\text { Ovitrap } \\
(-)\end{array}$ & & \\
\hline Tamansari 1 & 8 & 8 & 2 & 4 & 22 & $45 \%$ \\
\hline $\begin{array}{c}\text { FK Unisba } \\
\text { (Tamansari 22) }\end{array}$ & 3 & 1 & 1 & 2 & 7 & $57 \%$ \\
\hline Rektorat & 3 & 1 & 1 & 2 & 7 & $57 \%$ \\
\hline $\begin{array}{c}\text { Pascasarjana } \\
\text { Unisba }\end{array}$ & 1 & 3 & o & 1 & 5 & $20 \%$ \\
\hline Tamansari 20 & o & 2 & 1 & o & 3 & $33 \%$ \\
\hline Ranggagading & 1 & 4 & - & - & 5 & $20 \%$ \\
\hline Ranggamalela & 2 & 3 & o & 2 & 7 & $29 \%$ \\
\hline Jumlah & 18 & 22 & 5 & 11 & 56 & $41 \%$ \\
\hline
\end{tabular}

Berdasarkan atas hasil penyebaran ovitrap, hampir semua gedung di lingkungan Kampus Unisba telah didapatkan vektor penyakit demam berdarah dengue, yaitu nyamuk betina dewasa Aedes aegypti. Proporsi ovitrap positif yang disebar di Kampus Unisba adalah 41\%. Gedung di lingkungan Kampus Unisba dengan kepadatan vektor yang tertinggi adalah Gedung Fakultas Kedokteran Unisba Tamansari 22 dan Rektorat dengan proporsi ovitrap positif sebesar $57 \%$
Unisba, beberapa survei jentik di wilayah lain di Indonesia seperti Jawa Tengah dan Kalimantan juga mendapatkan hasil belum bebas jentik.5,6

Untuk mendapatkan lingkungan yang bebas jentik diperlukan partisipasi dari seluruh warga untuk menjaga kebersihan dan memberantas sarang-sarang nyamuk mempergunakan gerakan $3 \mathrm{M}$ plus, yaitu menguras tempat penampungan air bersih minimal satu minggu sekali, menutup tempat penampungan air, mengubur barang- 
barang bekas pakai yang dapat menampung air, memberikan bubuk abate pada air bersih di tempat penampungan air yang sulit dibersihkan, memelihara ikan pemangsa jentik nyamuk, serta mengatur ventilasi dan pencahayaan ruangan. Menguras tempat penampungan air paling sedikit satu minggu sekali bukan hanya pada tempat penampungan air besar seperti bak di kamar mandi, namun termasuk tempat penampungan air kecil seperti tempat penampungan air tumpah pada dispenser, serta tempat penampungan siraman air pada pot bunga dan pot tanaman air. ${ }^{3}$

Kepadatan nyamuk dewasa betina Aedes aegypti di Kampus Unisba berdasarkan indeks ovitrap termasuk tinggi. Keberadaan vektor penyakit DBD di Kampus Unisba memungkinkan terjadi penularan penyakit DBD apabila terdapat penderita DBD di lingkungan kampus sehingga pengendalian vektor sangat diperlukan dalam pencegahan penularan penyakit DBD. ${ }^{3}$ Penelitian di Mexico dan juga India mengenai keberadaan nyamuk Aedes aegypti di lingkungan sekolah dinyatakan bahwa kampus merupakan salah satu tempat potensial bagi penyebaran penyakit demam berdarah dengue. ${ }^{7,8}$ Apabila pengendalian vektor belum dilakukan dengan baik maka pelarangan datang ke kampus untuk penderita diperlukan agar nyamuk Aedes aegypti yang berada di lingkungan kampus tidak menularkan kepada orang lain. Penularan penyakit DBD didukung salah satunya oleh sifat nyamuk Aedes aegypti yang menghisap darah beberapa kali di dalam satu periode penghisapan darah untuk keperluan pematangan telur sehingga apabila nyamuk Aedes aegypti meghisap darah penderita DBD maka nyamuk tersebut dapat menyebarkan virus dengue ke beberapa orang di sekitar penderita tersebut. $^{2}$

Keberadaan nyamuk betina dewasa Aedes aegypti di dan sekitar Kampus Unisba merupakan hallazim karena Kota Bandung merupakan daerah endemis dan kasus demam berdarah /DBD terjadi sepanjang tahun. Selain itu, kepadatan nyamuk Aedes aegypti di kampus disebabkan oleh sifat diurnal nyamuk serta banyaknya mahasiswa, dosen, dan pegawai pada siang hari di kampus. Salah satu hal yang memengaruhi kepadatan nyamuk Aedes aegypti itu adalah keberadaan manusia sebagai penyedia darah untuk maturasi telur nyamuk. Semakin padat jumlah manusia di suatu tempat maka semakin banyak pula nyamuk Aedes aegypti yang berada di tempat tersebut. ${ }^{9}$

Aedes aegypti ternyata lebih menyenangi berada di dalam ruangan dibanding dengan di luar ruangan karena nyamuk menyukai tempat yang teduh. Sebaran nyamuk dipengaruhi oleh keberadaan manusia sebagai penyedia darah, ditunjang oleh tanaman, dan perabotan sebagai tempat peristirahatan. ${ }^{9}$ Selain itu, faktor ventilasi dan pencahayaan ruangan juga memengaruhi keberadaan vektor demam berdarah dengue. ${ }^{10}$ Jika ditelaah lebih lanjut, kepadatan nyamuk betina dewasa Aedes aegypti tertinggi di Gedung FK Unisba (Jalan Tamansari 22) lantai satu yang paling banyak terdapat pegawai dan mahasiswa berkumpul, serta terdapat pula tanaman dalam ruangan dan yang relatif padat dengan perabot. Selain itu, juga kurang dimasuki sinar matahari karena terhalang proyek pembangunan gedung baru. Demikian juga dengan tempat lain, tempat dengan kepadatannya nyamuk betina dewasa Aedes aegypti tinggi adalah tempat yang teduh, relatif yang padat dengan perabot dan manusia, serta terdapat tanaman dalam ruangan. Peneliti merekomendasikan untuk lebih menggiatkan gerakan PSN baik dilakukan oleh tim penyedia jasa kebersihan dan seluruh civitas academia Unisba agar tercapai target bebas jentik dari waktu ke waktu. Perencanaan tata ruang, ventilasi dan juga pencahayaan dalam gedung, tata letak tanaman dan perabotan dalam gedung juga harus diperhatikan dalam rangka pengendalian populasi nyamuk betina dewasa Aedes aegypti di dalam gedung Kampus Unisba. Penderita demam yang tersangka DBD dihimbau untuk tidak beraktivitas di kampus agar tidak menjadi sumber infeksi bagi yang lain.

\section{Simpulan}

Kampus Unisba Kelurahan Tamansari di Kota Bandung bukan merupakan daerah bebas jentik nyamuk Aedes aegypti dengan indeks kontainer sebesar $17 \%$ dan sudah tersebar vektor penyebar penyakit demam berdarah dengue, yaitu nyamuk betina dewasa Aedes aegypti dengan indeks ovitrap sebesar $41 \%$. 


\section{Daftar Pustaka}

1. WHO. Dengue guidelines for diagnosis, treatment, prevention and control. New edition. Geneva: WHO; 2009.

2. WHO. Dengue (diunduh 29 November 2014). Tersedia dari: http://www.who.int/topics/ dengue/en.

3. Kemenkes RI. DBD di Indonesia tahun 1968-2009. Bul Jendela Epidemiol. 2010;2: 1-14.

4. CDC. Dengue homepage entomology \& ecology (diunduh 29 November 2014). Tersedia dari: http://www.cdc.gov/dengue/ entomologyEcology $/ \mathrm{m} \_$lifecycle.html.

5. Subdirektorat Arbovirosis Ditjen P2M \& PL. Angka bebas jentik Indonesia 2005 (diunduh 12 Mei 2015). Tersedia dari: http://www.Sub direktorat+Arbovirosis+Ditjen+P2M+\%26+ PL,+2005.go.id/.

6. Boewono DT. Distribusi spasial kasus demam berdarah dengue (DBD), analisis indeks jarak dan alternatif pengendalian vektor di Kota Samarinda, Provinsi Kalimantan Timur. Media Litbang Kesehatan. 2012;22(3):131-7.

7. García-Rejón JE. Mosquito infestation and dengue virus infection in Aedes aegypti female in schools in Merida Mexico. Am J Trop Med Hyg. 2011;84(3):489-96.

8. Sharma RS, Panigrahi N, Kaul SM. Aedes aegypti prevalence in hospital and schools, the priority sites for DHF transmission in Delhi India. Dengue Bull. 2001;25:107-8.

9. Higa Y. Dengue vectors and their spatial distribution. Trop Med Health. 2011;39(4): 17-27.

10. Wahyono TYM, Haryanto B, Mulyono S, Adiwibowo A. Faktor-faktor yang berhubungan dengan kejadian demam berdarah dan upaya penanggulangannya di Kecamatan Cimanggis, Depok Jawa Barat. Bul Jendela Epidemiol. 2010;2:31-45. 